\title{
Profil literárnovedného výskumu Hviezdoslavovho diela
}

Ján Gbúr

\author{
GBÚR, J.: Profile of the Literary-Historical Research \\ of Hviezdoslav's Writing \\ SLOVENSKÁ LITERATÚRA, vol. 68, 2021, no. 6, pp. 583-591 \\ DOI: https://doi.org/10.31577/slovlit.2021.68.6.1 \\ ORCID ID: 0000-0003-4032-6382
}

\begin{abstract}
Key words: history of Slovak literature, Pavol Országh Hviezdoslav, reception of the work, literary research, Slovak dramatic literature of the 19th and 20th centuries, intersemiotic translation, intraliterary translation
\end{abstract}

\begin{abstract}
Although Pavol Országh Hviezdoslav $(1849$ - 1921) is probably the most well-known classic of the Slovak literature, his work has not been researched in its entire complexity. The article offers an overview of literature on his work and discusses the differences between methodologically sound scholarship -including interpretations of Hviezdoslav's work - and superficial affirmative biographies and compositional, structuralist versological, semantic and form-centred analyses. From the comparatist point of view, it addresses his early work in Hungarian and German, but it also points to his literary criticism, dramatic works, structured character of his poetics and the high artistic artifice of his depictive and expressive method. The article concludes with a set of topics and research areas which to this day have not been sufficiently addressed and hopes to elicit more scholarly attention in them.
\end{abstract}

Klúčové slová: dejiny slovenskej

literatúry, Pavol Országh Hviezdoslav, recepcia diela, literárnovedný výskum, slovenská dramatická literatúra 19. a 20. storočia, intersemiotický preklad, vnútroliterárny preklad 

d smrti azda najznámejšieho klasika slovenskej literatúry Pavla Országha Hviezdoslava uplynulo 8. novembra 2021 sto rokov. Je to pomerne dlhý čas na to, aby sa jeho dielo literárnovedne komplexne posúdilo. Nateraz však máme $k$ dispozícii len rozsiahly súbor čiastkových výskumných sond v podobe príležitostných príspevkov, zborníkových a časopiseckých štúdií a monografických prác, ktoré sú svedectvom zápasu najmä domácej literárnovednej (čiastočne aj jazykovednej) komunity o definovanie básnikovho umeleckého a ludského profilu a hl'adanie zmyslu jeho druhovo, žánrovo, tvarovo a poeticky mnohorozmerného diela pre národnú literatúru a kultúru, literárne a jazykové školské vzdelávanie a rozvoj živého literárneho dedičstva.

Ciel'om príspevku je urobit' ucelený pohl'ad na to, čo priniesol doterajší literárnovedný výskum Hviezdoslavovho diela, čo v ňom zarezonovalo ako seriózne metodologicky a interpretačne-výkladové bádanie a čo zostalo len na úrovni príležitostnej afirmatívnej biografie či formálno-štrukturalisticky zameraných verzologických, kompozičných, významových a tvarových analýz. Zámerom je tiež načrtnút' okruhy otázok, ktoré súvisia s málo prebádanými častami básnikovho diela, na ktoré by mala hl'adat' odpovede súčasná a budúca literárnovedná komunita.

Hviezdoslavovo dielo vznikalo v dotyku s inonárodnou, osobitne slovanskou, mad'arskou, nemeckou, anglickou a francúzskou literatúrou a kultúrou a tiež s domácou literárnou tradíciou (klasicistickou a romantickou). Na túto skutočnost', ktorá súvisí s básnikovými literárno-smerovými filiáciami a jeho komplikovaným trojitým vstupovaním do literatúry (prvý vstup cudzojazyčný, druhý neskororomantický a tretí vlastný vstup básňami nevydanej zbierky Krb a vatra), upozornili viacerí bádatelia pozitivistickej literárnovednej orientácie (osobitne Bujnák 1924; Kostolný 1949; Votruba 1950: 162-168; Pražák 1955; Bolek 1969; Kiškin 1971), no novátorský prístup do literárno-komparatívneho spôsobu bádania vniesol František Miko (Miko 1982). Pripomenul dôležitý fakt, že toto vstupovanie zahŕňalo nielen zložitú situáciu v domácom literárno-kultúrnom kontexte, ale aj literárnu situáciu v inonárodných literatúrach, ktorú slovenský básnik sledoval, recipoval a čiastočne sa ňou inšpiroval najmä vo svojom ranom diele.

Literárnohistoricky najprítažlivejšou témou komparatistickej problematiky bol vztah Hviezdoslavovej tvorby k českej literatúre a kultúre a vztah českej literatúry a kultúry $\mathrm{k}$ jeho osobe a dielu. $\mathrm{O}$ týchto reláciách vzniklo množstvo paušálne formulovaných názorov, indícií a postrehov o jednostrannej závislosti slovenského básnika od jeho českých literárnych vzorov (Jaroslav Vrchlický, Jan Neruda, Vítězslav Hálek, Svatopluk Čech a iní), ale aj prvých príležitostných literárnych biografií vydaných ešte za básnikovho života alebo krátko po jeho smrti (Táborský 1919; Tichý 1920; Pražák 1909; Bujnák 1919; Krčméry 1921), ktoré rozvinuli básnikov funkčne upravený obraz, plniaci v spoločnosti aj iné ako primárne esteticko-umelecké funkcie. Danej problematike bola venovaná aj samostatná publikácia analyzujúca interno- a externokontaktové vzt'ahy a typologické súvislosti Hviezdoslava s českou literatúrou a kultúrou a približujúca českú cestu vytvárania uvedeného obrazu Hviezdoslava ako národnej literárnej ikony (Gbúr 1998).

Výskum česko-slovenskej vzájomnosti a proklamovanej československej spolupráce s víziou budúcej politickej jednoty, ktorý svojou tvorbou, ale aj spoločensko-kultúrnymi a politickými aktivitami ovplyvňoval aj Hviezdoslav, nie je zd'aleka ukončený. Osobitnú kapitolu vzt'ahu slovenského básnika k českému 
literárnemu a kultúrnemu prostrediu tvorili jeho kontakty s českým literárnym $\mathbf{5 8 5}$ historikom Albertom Pražákom. Podstatná čast' výskumu tohto vztahu je ukončená (Pišút 1961; Tomčík 1976; Gbúr 1998; Vojtech 2007; Zelenková 2017), otvorená zostáva problematika Pražákovej interpretácie Hviezdoslava ako zástancu ideológie unitaristického „čechoslovakizmu“ a zhodnotenie doteraz neobjaveného textového materiálu z pozostalosti A. Pražáka, ktorý by mohol priniest' nové poznatky o súkromnom a pracovnom rozmere slovenského básnika. Dôležitú úlohu v Hviezdoslavovej slovakofilskej orientácii zohrali Hynek Babička, Jiří Polívka, Rudolf Pokorný, ale aj autori takzvanej Mladej Moravy, ktorú tvorili brnianski a olomouckí študenti združení od roku 1876 okolo almanachu moravskej mládeže Zora. Základný výskum uvedených externokontaktových medziliterárnych filiácií slovenského básnika s českým literárnym prostredím bol síce už realizovaný (Pešta 1959; Zelenková 2009a, 2009b; Gbúr 2021), no typologický rozmer uvedených filiácií ešte čaká na spracovanie.

Pozitivisticky orientovaná literárna veda sa v súvislosti s tvorbou mladého Hviezdoslava zameriavala na vyhl'adávanie a identifikáciu jeho vztahov $\mathrm{s}$ autormi, ktorých diela recipoval. V súvislosti s jeho vnútrotextovým nadväzovaním na diela autorov mad'arskej romantickej literatúry (Sándor Petöfi, Mihály Vörösmarty, János Arany) sa stretávame s viacerými jednostrannostami v ich hodnotení. Napríklad slovenský literárny historik a hungarista Pavel Bujnák pri analýze Hviezdoslavových mad'arských prvotín naznačil určitú formu jeho závislosti od poetiky spomínaných mad’arských básnikov (Bujnák 1924). Literárny historik László (Ladislav) Sziklay vo viacerých svojich štúdiách (Sziklay 1938, 1956, 1962a, 1962b, 1965, 1972, 1973) označil Hviezdoslava za jedného z viacerých inonárodných epigónov Petöfiho. V monografii Az ifjú Hviezdoslav (Mladý Hviezdoslav, 1965) dospel dokonca k ideologickému záveru, že Hviezdoslav je kliesnitel'om cesty k „zmiereniu Mad'arov a Slovákov“ (Sziklay 1965: 39). Pri hĺbkovej analýze recepcie po mad'arsky napísanej básne z roku 1867 Öszi gondolatok a jej slovenského prekladu (Jesenné myšlienky) dospeli Tibor Zsilka a Marta Zsilková k viacerým záverom, ktoré naznačili problémy nielen pri identifikácii hodnotových parametrov Hviezdoslavovej poézie v školskej praxi, ale aj pri skúmaní vzt'ahu Hviezdoslava k mad'arskej literárnej tradícii (Zsilka - Zsilková 1975). Problematika literárnosmerových filiácií a sugescií mladého Hviezdoslava $\mathrm{k}$ autorským umeleckým projekciám mad'arskej literatúry nie je nateraz dostatočne zhodnotená. V jej skúmaní treba pokročit', pretože predstavuje jeden zo základov konštituovania básnikovej hodnotovo-umeleckej orientácie. Najnovšie to potvrdila štúdia o jeho mad'arskej epickej básni Tompakö, nájdenej v Pražákovej pozostalosti, ktorá odhalila zaujímavé súvislosti použitého povestového materiálu zo slovenského prostredia (Gbúr-Zelenková 2017).

Hviezdoslavova po nemecky písaná poézia, ktorá vznikla počas jeho gymnaziálnych štúdií v Kežmarku (1865-1870), má viac-menej epizodický charakter. Dve staršie štúdie, ktoré jej venovali odbornú pozornost' (Lazar 1974; Petraško 1975), konštatovali, že korešponduje s autorovou juvenílnou, po slovensky, respektíve po mad'arsky písanou poéziou inklinujúcou k romantickej poetike. Vzhl'adom na to, že čast' tejto poézie je ešte uschovaná v archívoch, otvára sa priestor najmä pre germanisticky orientovaných literárnych vedcov na jej podrobnejší výskum. 

nokritická činnost'. Venoval sa jej len krátko počas pobytu na právnickej akadémii v Prešove v rokoch 1870 - 1872. Nateraz ide o kritiky dvoch literárnych prác Kolomana Banšella uverejnených v almanachu Napred, predtým prednesených v prešovskom študentskom krúžku Kolo (Lazár 1940). Prvý posudok má názov Kritika na Šuhaj ako z iskry (Povahopisné obrázky), druhý Úsudok na báseň Rozpomienka na Zemplín. Obidva kritické texty boli dlhší čas verejnosti neznáme, po ich objavení v jednom z pražských antikvariátov boli uložené v Literárnom archíve Slovenskej národnej knižnice v Martine. ${ }^{1}$ Prvý raz ich spomenul Stanislav Šmatlák vo svojej monografii o Hviezdoslavovej lyrike (Šmatlák 1961: 87, 426), pričom v plnom znení aj s krátkym komentárom ich publikoval Peter Liba v regionálnom zborníku Nové obzory (Liba 1964). Hoci literárnokritická činnost'mladého Hviezdoslava má v porovnaní s jeho ostatnou tvorbou viac-menej epizodický charakter, pre dejiny slovenskej literárnej kritiky a zvlášt pre poznanie „napredovských" tvorivých literárno-umeleckých a literárnokritických aktivít je vel'mi cenná. Z uvedených dôvodov bude potrebné rozvinút doterajšie poznámky na túto tému o analytický rozbor Országhových kritík, určit' ich hodnotový rozmer, zistit', či ich literárnokritická metóda je ovplyvnená autorovým umeleckým názorom alebo dobovou literárnokritickou praxou.

Základné dramatické práce P. O. Hviezdoslava tvoria tri hry z jeho raného tvorivého obdobia (Vzhledanie, 1868; Pomsta, 1869; Otčim, 1871) a dráma Herodes a Herodias z roku 1909. Treba zdôraznit', že slovenská literárna história i teatrológia im venovali značnú výskumnú pozornost'. Prvá väčšia štúdia o Hviezdoslavových dramatických textoch, ktorej autorom bol P. Bujnák, si všímala predovšetkým ich ideovú a dejovú (sčasti teatrologickú) zložku (Bujnák 1919). A. Pražák v memoárovej práci $S$ Hviezdoslavom tematicky utriedil Hviezdoslavove rané dramatické fragmenty, ktoré, žial', nemožno d'alej skúmat', pretože sa dodnes nenašli (Pražák 1955: 204-330). S. Šmatlák, popredný znalec básnikovho diela a autor doteraz jedinej monografie o Hviezdoslavovej lyrickej tvorbe (Šmatlák 1961), uvedenú problematiku len stručne glosoval, čo sa výrazne prejavilo najmä v tret'om zväzku takzvaných akademických Dejín slovenskej literatúry (Čepan-Kusý-Šmatlák - Noge 1965) a v jeho vlastných autorských dejinách slovenskej literatúry (Šmatlák 1988). Naopak, podrobnú analýzu charakterov a kompozično-fabulačnej štruktúry tretej publikovanej divadelnej hry mladého Hviezdoslava Otčim urobil Pavol Petrus (Petrus 1971) a na podklade Hviezdoslavovej dramatickej tvorby realizoval Anton Popovič špecializovaný výskum utvárania slovenského blankversu (Popovič 1965). Doteraz najkomplexnejšiu literárnovednú analýzu dramatického diela Hviezdoslava urobil Ján Gbúr (Gbúr 2009). Do jeho výskumnej pozornosti sa nedostal iba dramatický fragment $\mathrm{Na} \mathrm{Luciu} \mathrm{z} \mathrm{roku} \mathrm{1904,} \mathrm{ktorého} \mathrm{osobitostou} \mathrm{je}$ torzovitá štruktúra textu, dialogizovaná veršová forma a absencia komplexného scénického poznámkového aparátu. Slovenská teatrológia analyzovala danú čast' Hviezdoslavovej umeleckej činnosti v kontexte slovenskej dramatickej literatúry 19. a začiatku 20. storočia, ale aj v súvislosti s jej inscenačnými realizáciami

1 Slovenská národná knižnica v Martine, Literárny archív, osobný fond Pavol Országh Hviezdoslav, signatúry $70 \mathrm{~S} 8,70 \mathrm{~S} 2$. 
(Cesnaková-Michalcová - Noskovič - Čavojský - Lehuta 1967: 384-407; Encyklopédia... 1989: 505; Pašteka 1979, 1990, 1998; Jaborník 2018).

Hviezdoslavovo celoživotné úsilie smerovalo k napĺňaniu celistvého modelu básnika (Mikula 2019: 51), ktorý chcel v oblasti literatúry obsiahnut' všetky druhy a žánre, čo sa mu čiastočne aj podarilo (Hvišč 1976). Nevytvoril iba prozaické útvary, ktoré dominovali v epoche realizmu, lebo, ako zdôrazňoval, je lyrik, prózu (epiku) nevie písat. Uvedený problém vyriešil tak, že podstatnú čast' svojej tvorby realizoval vo veršovanej epike. Riešenie uvedeného literárneho problému u Hviezdoslava bolo natol'ko špecifické, že ním zaujal pozornost' literárnej kritiky, teórie a histórie (Mečiar 1939; Šmatlák 1961; Turčány 1956, 1963, 1975; Bakoš 1966a, 1966b: 137-182; Miko 1974; Zajac 1976; Liba 1976; Gbúr -Sabol 2014; Matiaška 2001 a iní). Ďalší výskum by sa mohol týkat špecifických otázok jeho epickej, osobitne baladickej tvorby, ale aj prechodných lyricko-epických žánrových foriem či otázok prekladov, ktoré sú zo všetkých Hviezdoslavových umeleckých aktivít najmenej rozpracované.

Hviezdoslavova poetika je zložito štruktúrovaná. Z toho dôvodu je náročné urobit' jej opis, usporiadat' ju podl'a druhových, smerových, vývinových a ideovo-spoločenských charakteristík. Prvé pokusy charakterizovat' básnikovu poetiku, jej štýlové a výrazové parametre mali svoje metodologické obmedzenia v tom, že uprednostňovali opisnost' jednotlivých textových zložiek, psychologizovali emočno-hodnotové vrstvy slovesného diela a otázky veršových foriem vysvetl'ovali zväčša mechanickou aplikáciou kvantitatívnych metód (Bujnák 1919; Mečiar 1939; Kostolný 1949; Votruba 1950; Štraus 1995). Okrajovo sa dotkli autorových vyjadrovacích osobitostí, pomenovali niektoré zložky emblémových znakov v jeho realisticky či romanticky koncipovaných epických príbehoch a tvarových a vyjadrovacích osobitostí v lyrických básňach, avšak osobitne neanalyzovali znaky jeho dominantnej poetiky „vysokého štýlu“, , artistnej“ básnickej kultúry, ktorá sa prejavuje na úrovni výrazu, syntaxe, verša, strofy, žánru, témy, lyrického obrazu, látkového podložia, univerzalizmu takzvaných večných hodnôt (l'udstvo, vesmír, pravda, krása, sloboda, pokrok a iné). Modelový opis znakov Hviezdoslavovej umeleckej metódy urobil až F. Miko, ktorý funkčne využil svoj komunikačno-semiotický štylistický model literárneho textu na to, aby analyzoval súbor znakov, ktoré pomenoval „vysokým štýlom“, pričom ho dal do spojitosti s otázkou emocionálne, funkčne a spoločensky prehodnoteného parnasizmu (Miko 1975: 14-20; Gbúr 2015; Haman - Tureček 2015). Treba zdôraznit', že skupina znakov „vysokého štýlu“ je vel'mi výrazná, prestupuje druhové a žánrové hranice Hviezdoslavových textov, ba dotýka sa aj jeho prekladatel'skej metódy (Popovič 1965). Je to d'alšia výskumne otvorená téma.

Problematika Hviezdoslavovho umeleckého vyjadrovania, osobitne jeho „vysokého štýlu“, bola už za básnikovho života živou témou čitatel'ov jeho diel, ale aj dobovej literárnovednej komunity, ktorá sa usilovala pochopit' motiváciu existencie „vysokých“ a „nízkych“ polôh jeho poetiky. Tento problém rozvinuli štúdie Petra Zajaca, Valéra Mikulu, čiastočne aj Blažeja Beláka. Poukázali na skutočnost', že otázka „vysokého“a „nízkeho“v Hviezdoslavovej zobrazovacej a vyjadrovacej metóde je len častou komplexného vnímania básnika ako vzoru klasika, ,zmyslom života ktorého je tvorenie“ (Mikula 2019: 51). Táto celoživotná aktivizujúca umelecká profilácia Hviezdoslava narážala na jeho postulovanú, mýtotvornú obrodenecko-romantickú profiláciu ako užitočného a pre národ potrebného tvorcu 
588 umeleckého slova. V tomto zmysle prebral na seba dve funkcie užitočnosti. Jedna bola subjektívna, umelecká, básnická, druhá zasa spoločensko-pragmatická. V. Mikula identifikoval v týchto funkciách obraz Hviezdoslava ako „hodnotovo ambivalentného" klasika vystupujúceho ako synekdochický obraz našej literatúry a kultúry (Mikula 2019: 59). P. Zajac vyslovil tézu, že uvedený mýtotvorný proces vytvoril známy ,antinomický model Hviezdoslava - ,najväčšieho‘ slovenského a zároveň nezrozumitel'ného [a nečítaného, v konečnom dôsledku nepoznaného - poznámka J. G.] autora" (Zajac 1976: 62).V tejto súvislosti pripomeniem írskeho básnika a prekladatel'a Johna Minahana, ktorý je autorom najnovšieho prekladu Hviezdoslavových Krvavých sonetov do angličtiny (Hviezdoslav 2018). Vo svojej štúdii Moderný, nie módny: Hviezdoslav 1909-1914, ktorá je čiastočne venovaná uvedenému prekladu, ale najmä básnickému naturelu Hviezdoslava, polemizoval s „doktrinárskymi“ argumentmi V. Mikulu o mýtotvornom a automýtotvornom rozmere básnikovho naturelu (Minahane 2019). Namiesto toho ponúkol domácimi kultúrno-literárnymi problémami nezatažený, „vel'korysejší, širší a otvorenejší “ prístup: „Je to človek, ktorý myslí inak. Nekráča s módou svojich vlastných čias ani v súlade stereotypných príbehov progresu“ (Minahane 2019:372).

Tento proces si Hviezdoslav bolestne uvedomoval už na rozhraní 19. a 20. storočia (Zajac 2005), v čase, ked'mal pätdesiat rokov. Napriek tejto recepčne nepriaznivej situácii nemienil zmenit' svoj umelecký naturel. V básni Netrápte sa, piesne moje z roku 1903 naznačil vtedajšej čitatel'skej verejnosti, že jeho dielo nebolo a nebude nikdy zdrojom duševného oddychu či mimoliterárnych pragmatizmov, ale, naopak, bude podnetom $\mathrm{k}$ tvorivému dialógu o zmysle básnického umenia: „neviete byt' [„,piesne moje“ - doplnil J. G.] l'ahké“, „,neviete sa klonit“, „zriedkavésú dary ducha“, „nesnádno každému sa prispôsobit" (Hviezdoslav 1903: 208). Tieto básnikove slová platia aj pre súčasnú recepciu jeho poézie. Určité možnosti, ako riešit' tento problém, ako umožnit' súčasnému čitatelovi recipovat' básnikove texty pri zachovaní ich pôvodných umeleckých kvalít a originálnych špecifík, čiastočne naznačila doterajšia edičná prax pri vydávaní jeho diel. Ukazuje sa, že dobrými pomôckami pri recipovaní jeho textov sú intersemiotické preklady (televízne a filmové adaptácie a spracovania) ${ }^{2}$ a vnútrotextové preklady autorových epických príbehov (Hviezdoslav - Mihálik 1974; Zajac 1975), ale aj moderné školské formy komunikácie s básnikovým dielom. Pre súčasnú, ale najmä pre budúcu literárnovednú komunitu s diskurzívnymi recepčnými danostami môže byt'Hviezdoslavovo dielo príležitostou na introvertne zacielené výklady jeho poetologicky náročných básnických textov. Pozitívnym príkladom je zborník Hviezdoslavvinterpretáciách (Zambor 2009), v ktorom sa svojimi analýzami Hviezdoslavových básní predstavili viacerí slovenskí literárni vedci so skúsenostami s interpretáciou básnických

2 Výberovo: televízna inscenácia Hájnikova žena, 1971, scenár a réžia Jozef Pálka; televízna inscenácia Ežo Vlkolinský, 1978, scenár a réžia J. Pálka; televízna inscenácia Gábor Vlkolinský, 1978, scenár a réžia J. Pálka; televízny film Zuzanka Hraškovie, 1991, scenár Vincent Šikula, réžia Franek Chmiel; divadelná inscenácia Hájnikova žena, 2015, „,poetický obraz na bielom plátne“, Spišské divadlo v Spišskej Novej Vsi, premiéra 9. januára 2015, réžia Kamil Žiška, dramaturgia Tibor Kubička; Časy, časy, mrcha časy, 2017, divadelné predstavenie menej známych Hviezdoslavových textov (Pomsta mŕtvych; Del'ba dedičstva; Noc je; Časy, časy, mrcha časy), Slovenské národné divadlo v Bratislave, premiéra 29. apríla 2017, réžia Peter Weinciller, dramaturgia Miriam Kičiňová; Ó sláva hviezd ó sláva, 2017, divadelné predstavenie troch balád P. O. Hviezdoslava (Margita, Zuzka Majerovie, Anča), Slovenské národné divadlo v Bratislave, premiéra 29. apríla 2017, réžia P. Weinciller, dramaturgia Juraj Fotul. 
textov rozličnej slohovo-žánrovej a poetologickej výbavy. Uvedené spôsoby recepcie básnikovej tvorby, ku ktorým možno pričlenit štúdie J. Minahana (Minahane 2019), J. Zambora (Zambor 2019) a Mariána Andričíka (Andričík 2019) na tému básnikových Krvavých sonetov, môžu byt' začiatkom cesty k tomu, ako postupne vrátit' Hviezdoslava z mimoliterárneho života do života umeleckej literatúry.

Štúdia je výstupom grantového projektu APVV-19-0244 Metodologicképostupy v literárnovednom výskume s presahom do mediálneho prostredia. Zodpovedný riešitel': prof. PhDr. Ján Gbúr, CSc. Doba riešenia: 2020 - 2024.

\section{Pramene}

HVIEZDOSLAV, Pavol Országh, 1903. Netrápte sa, piesne moje. Slovenské pohl'ady, roč. 23, č. 4, s. 208-209.

HVIEZDOSLAV, Pavol Országh-MIHÁLIK, Vojtech, 1974. Hviezdoslav vo výbere a interpretácii Vojtecha Mihálika. Bratislava: Slovenský spisovatel'.

HVIEZDOSLAV, Pavol Országh, 2018. The Bloody Sonnets. The Introduction and Biographical Notes Written and Translated John Minahane. Bratislava: Literárne informačné centrum. ISBN 9788081191145 .

\section{Literatúra}

ANDRIČÍK, Marián, 2019. Minahanov preklad Hviezdoslavových Krvavých sonetov. In Studia Academica Slovaca 48. Prednášky 55. letnej školy slovenského jazyka a kultúry. Bratislava: Univerzita Komenského, s. 398-480. ISBN 978-80-223-4774-7.

BAKOŠ, Mikuláš, 1966a. Hviezdoslavov lyrický verš. Slovenská literatúra, roč. 13, č. 6, s. 543-566.

BAKOŠ, Mikuláš, 1966b. Vývin slovenského verša od školy Štúrovej. Tretie doplnené vydanie. Bratislava: Veda.

BOLEK, Anton, 1969. Hviezdoslavove slovanskéliterárne vzt'ahy. Acta Facultatis Philosophicae Universitatis Šafarikanae Prešoviensis. Bratislava: Slovenské pedagogické nakladatel'stvo.

BUJNÁK, Pavel, 1919. Sobrané kritiky I. (Hviezdoslav). Knižnica mladého Slovenska č. 2. Bratislava: Nákladom O. M. S., Kníhtlačiareň Politika v Prahe, s. 59-158.

BUJNÁK, Pavel, 1924. Ján Arany v literatúre slovenskej. Úvaha z oboru srovnávacích dejin literárnych. Praha: FF UK.

CESNAKOVÁ-MICHALCOVÁ, Milena-NOSKOVIČ, Alexander-ČAVOJSKÝ, Ladislav-LEHUTA, Emil, 1967. Kapitoly z dejín divadla od najstaršich čiaspo realizmus. Bratislava: Veda.

ČEPAN, Oskár - KUSÝ, Ivan - ŠMATLÁK, Stanislav - NOGE, Július, 1965. Dejiny slovenskej literatúry. III. Literatúra druhej polovice 19. storočia. Bratislava: Veda.

ENCYKLOPÉDIA dramatických umení Slovenska. 1. A - L, 1989. Bratislava: Veda. ISBN 80-224-0000-9.

GBÚR, Ján, 1998. Hviezdoslav a česká poézia. Prešov: Náuka. ISBN 80-967602-4-6.

GBÚR, Ján, 2009. Hviezdoslav. Dramatická tvorba. Košice: Equlibria. ISBN 978-80-89284-35-1.

GBÚR, Ján, 2015. Hviezdoslav a Vrchlický alebo O jednom medziliterárnom parnasistickom podnete. In HAMAN, Aleš-TUREČEK, Dalibor, ed. Český a slovenskýliterární parnasismus: synopticko-pulzační model kulturního jevu. Brno: Host, s. 272-292. ISBN 9788074912559.

GBÚR, Ján, 2021. Príležitostná literárna biografia P. O. Hviezdoslava z pohl'adu Františka Táborského a doterajšieho literárnovedného výskumu na Slovensku. Slavica litteraria, roč. 24, č. 1, s. 89-102. ISSN 1212-1509.

GBÚR, Ján-SABOL, Ján, 2014. Veršv štruktúre básnického textu. Acta Facultatis Philosophicae Universitatis Šafarikianae 17., Filozofická fakulta UPJS v Košiciach, Košice: Univerzita Pavla Jozefa Šafárika. ISBN 978-80-8152-220-8.

HAMAN, Aleš-TUREČEK, Dalibor, ed., 2015. Českýa slovenskýliterárníparnasismus: synopticko-pulzační model kulturního jevu. Brno: Host. ISBN 9788074912559.

HVIŠČ, Jozef, 1976. Žánrový model literárnej biografie P. O. Hviezdoslava. In Biografistika v systéme literárneho vzdelania. Acta Musei Litterarii Pauli Országh-Hviezdoslav. Dolný Kubín: Literárne múzeum P. O. Hviezdoslava-Nitra: Kabinet literárnej komunikácie a experimentálnej metodiky Pedagogickej fakulty, s. 40-58. 
JABORNÍK, Ján, 2018. Hviezdoslavova literatúra a Hviezdoslavovo divadlo (Nad inscenačnými peripetiami tragédie Herodes a Herodias). In Ján Jaborník. Historik, teoretik a kritik divadla. Bratislava: Divadelný ústav, s. 379-393. ISBN 978-80-8190-041-9.

KIŠKIN, Lev Sergejevič, 1971. Ruská próza vo Hviezdoslavovej percepcii. Slovenská literatúra, roč. 18 , č. 6 , s. 548-556.

KOSTOLNÝ, Andrej, 1949. Pavol Országh-Hviezdoslav. Bratislava: Štátne nakladatel'stvo.

LAZÁR, Ervín, 1940. Prešovské roky Pavla Országha Hviezdoslava. In Sborníkprác profesorov evanjelického kolegiálneho slovenského gymnázia v Prešove. Prešov: Nákladom evanjelického kolégia v Prešove, s. 71-96.

LAZAR, Ervín, 1974. Nemecké básnické pokusy Pavla Országha-Hviezdoslava. In Literárny archív 10/73. Martin: Matica slovenská, s. 265-297.

LIBA, Peter, 1964. Hviezdoslavove kritiky z prešovského „Kola“. In Nové obzory 6. Košice: Východoslovenské vydavatel'stvo, s. 146-167.

LIBA, Peter, 1975. Hviezdoslavove príležitostné básne. In P. O. Hviezdoslav. Text a kontext. Dolný Kubín: Literárne múzeum P. O. Hviezdoslava-Nitra: Kabinet literárnej komunikácie a experimentálnej metodiky Pedagogickej fakulty, s. 91-124.

MATIAŠKA, Milan, 2001. Povaha digresie vo Hviezdoslavovej epike. Slovenská literatúra, roč. 48 , č. 3, s. 185-190. ISBN 0037-6973.

MEČIAR, Stanislav, 1939. Hviezdoslavova Hájnikova žena. Rozbor a hodnotenie. Martin: Matica slovenská.

MINAHANE, John, 2019. Moderný, nie módny: Hviezdoslav 1909-1914. In Studia Academica Slovaca 48. Prednášky 55. letnej školy slovenského jazyka a kultúry. Bratislava: Univerzita Komenského, s. 361-374. ISBN 978-80-223-4774-7.

MIKO, František, 1974. Od epiky k lyrike. Bratislava: Tatran.

MIKO, František, 1975. Pavol Országh Hviezdoslav - problém výkladu textu ako problém poetiky. In P. O. Hviezdoslav. Text a kontext. Dolný Kubín: Literárne múzeum P. O. Hviezdoslava - Nitra: Kabinet literárnej komunikácie a experimentálnej metodiky Pedagogickej fakulty, s. 6-26.

MIKO, František, 1982. Inovácia a syntéza u P. O. Hviezdoslava. In Hodnoty a literárny proces. Bratislava: Tatran, s. 225-256.

MIKULA, Valér, 2019. Hviezdoslav ako automýtus. In MIKULA, Valér. Štúdie a eseje. Levice: KK Bagala. ISBN 978-80-89973-35-4.

PAŠTEKA, Július, 1979. Umelecké princípy Hviezdoslavovej dramatiky (Niekol'ko analytických poznámok v jubilejnom roku). Slovenské divadlo, roč. 27, č. 3, s. 273-338.

PAŠTEKA, Július, 1990. Slovenská dramatika v epoche realizmu. Bratislava: Tatran, s. 219-233. ISBN 80-222-0185-5.

PAŠTEKA, Július, 1998. Pohl'ady na slovenskú dramatiku, divadlo a kritiku. I. Bratislava: Národné divadelné centrum, s. 85-109. ISBN 80-8545-562-5.

PEŠTA, Pavel, 1959. Ze vztahu Františka Táborského k literárnímu Slovensku. Slovenská literatúra, roč. 6 , č. 1, s. 48-49.

PETRAŠKO, Ludovít, 1975. Interpretácia nemeckej poézie P. O. Hviezdoslava. In P. O. Hviezdoslav. Text a kontext. Dolný Kubín: Literárne múzeum P. O. Hviezdoslava - Nitra: Kabinet literárnej komunikácie a experimentálnej metodiky Pedagogickej fakulty, s. 149-158.

PETRUS, Pavol, 1971. Hviezdoslavova činohra Otčim. In Východné Slovensko v literárnych dejinách. Martin: Matica slovenská - Pamätník slovenskej literatúry, s. 177-187.

PIŠÚT, Milan, 1961. Albert Pražák a jeho stretnutia s Hviezdoslavom. In PIŠÚT, Milan. Roky a diela. Bratislava: Slovenský spisovatel'.

POPOVIČ, Anton, 1965. Slovenský blankvers (K vývinu dramatickej veršovej formy). In Litteraria VIII. Z historickej poetiky II. Bratislava: Veda, s. 162-187.

PRAŽÁK, Albert, 1909. Básnické dílo Pavla Országha-Hviezdoslava. Několik poznámek k jeho vývoji. Slovanský přehled, roč. 11, č. 5-6, s. 194-208.

PRAŽÁK, Albert, 1924. Mad'arské vlivy v slovenské literatuře. Nová svoboda, roč. 1, č. 14, s. 228-230.

PRAŽÁK, Albert, 1955. S Hviezdoslavom. Bratislava: Slovenské vydavatel'stvo krásnej literatúry. SZIKLAY, László, 1938. Hviezdoslav. Egyetemes Philologiai Közlöny, roč. 62, č. 10-12, s. 354-372. SZIKLAY, László,1962a. A szlovák irodalom története. Budapest: Akadémiai Kiadó.

SZIKLAY, László, 1962b. Hviezdoslav két ismeretlen Petöfi fordítása. Világirodalmi Figyelö, roč. 8, č. 1, s. 51-55.

SZIKLAY, Ladislav, 1956. Hviezdoslavove mad'arské prvotiny. Slovenská literatúra, roč. 3, č. 1, s. 37- 68 . 
SZIKLAY, László, 1958. Hviezdoslav und die ungarische Literatur. Studia Slavica Hungaricae roč. 4, č. 1-2, s. 193-210.

SZIKLAY, László, 1965. Az ifjú Hviezdoslav. Budapest: Akadémiai Kiadó.

SZIKLAY, Ladislav, 1973. Problémy slovenskej a mad'arskej histórie v zrkadle študentských rokov P. O. Hviezdoslava. In Úkoly historiografie střední, východní a jihovýchodni Evropy vobdobí socialistické integrace. Brno: Univerzita J. E. Purkyně, s. 106-112.

SZIKLAY, László, 1972. Z komparatívnych problémov hviezdoslavológie. Slovenská literatúra, roč. 19 , č. 2, s. 177-189.

ŠMATLÁK, Stanislav, 1961. Hviezdoslav. Zrod a vývin jeho lyriky. Bratislava: Slovenské vydavatel'stvo krásnej literatúry.

ŠMATLÁK, Stanislav, 1988. Dejiny slovenskej literatúry od stredoveku po súčasnost'. Bratislava: Tatran.

ŠTRAUS, František, 1995. Strofa a metrum v poézii P. O. Hviezdoslava. Bratislava: Univerzita Komenského. ISBN 80-223-0653-3.

TOMČÍK, Miloš, 1976. Vývin Pražákovho záujmu o Pavla Országha-Hviezdoslava. In Literárne dvojobrazy. Bratislava: Slovenské pedagogické nakladatel'stvo, s. 86-127.

TURČÁNY, Viliam, 1956. Hviezdoslavov epický obraz dediny pred „Vlkolínom“. Slovenská literatúra, roč. 3, č. 2, s. 144-163.

TURČÁNY, Viliam, 1963. Hviezdoslavova kratšia epika. In Literatúra a jazyk. Litteraria VI. Bratislava: Veda, s. 193-251.

TURČÁNY, Viliam, 1975. Rým v slovenskej poézii. Bratislava: Veda, s. 127-176.

VOJTECH, Miloslav, 2007. Básnik v spomienkach literárneho historika. In Studia Academica Slovaca 36. Bratislava: Stimul, s. 271-283. ISBN 978-80-89236-23-7.

VOTRUBA, František, 1950. Literárne štúdie. Texty z rokov 1909-1922-Sväzokprvý. Bratislava: Slovenský spisovatel', s. 133-205.

ZAJAC, Peter, 1975. Ežo Vlkolinský a jeho prepis do prózy. In P. O. Hviezdoslav. Text a kontext. Dolný Kubín: Literárne múzeum P.O. Hviezdoslava-Nitra: Kabinet literárnej komunikácie a experimentálnej metodiky Pedagogickej fakulty, s. 71-90.

ZAJAC, Peter, 1976. Portrét básnika. In Biografistika v systéme literárneho vzdelania. Acta Musei litterarii Pauli Országh-Hviezdoslav. Dolný Kubín: Literárne múzeum P. O. Hviezdoslava - Nitra: Kabinet literárnej komunikácie a experimentálnej metodiky Pedagogickej fakulty, s. 59-76.

ZAJAC, Peter, 2005. Básnik konca. Slovenská literatúra, roč. 52, č. 1, s. 3-13. ISBN 0037-6973.

ZAMBOR, Ján, ed., 2009. Hviezdoslav v interpretáciách. Bratislava: Literárne informačné centrum. ISBN 978-80-89222-78-0.

ZAMBOR, Ján, 2019. Interpretačná sonda do Hviezdoslavových Krvavých sonetov. In Studia Academica Slovaca 48. Prednášky 55. letnej školy slovenského jazyka a kultúry. Bratislava: Univerzita Komenského, s. 375-397. ISBN 978-80-223-4774-7.

ZELENKOVÁ, Anna, 2009a. Medzi vzájomnostou a nevzájomnostou. Sondy do česko-slovenských a slovensko-českých literárnych vztáahov. Praha-Nitra: Slovanský ústav AV ČR-Filozofická fakulta UKF. ISBN 978-80-86420-34-9, 978-80-8094-648-7.

ZELENKOVÁ, Anna, 2009b. Metodologické reflexie a východiská česko-slovenských a slovensko-českých literárnych vztahov. Slavica Litteraria, roč. 12, č. 2, s. 3-29. ISSN 1212-1509.

ZELENKOVÁ, Anna, 2017. Voz'raščenie k semejnomu nasledstvu Alberta Pražáka i Pavlu Orszagu Gvezdoslavu. In MATEJKO, L'ubor, ed. Literature and Social Change: A Voyage Trough the History of Slavic Studies. Proceedings of the International Symposium "Literature and Slavic Studies" held by the Commission for the History of Slavic Studies at the Comenius University in Bratislava on the 12th and 13th of April 2016. Bratislava: Porta Danubiana, s. 205-212. ISBN 978-80-971479-3-8.

ZELENKOVÁ, Anna - GBÚR, Ján, 2017. Unknown Hungarian First Fruits of the Slovak Poet Pavol Országh Hviezdoslav (A Contribution to the Slovak-Hungarian Bi-literary Stance). Neohelicon, roč. 44, s. 469-485. ISSN 0324-4652.

Prof. PhDr. Ján Gbúr, CSc. ZSILKA, Tibor - ZSILKOVÁ, Marta, 1975. Analýza recepcie mad'arskej prvotiny Pavla Országha-Hviezdoslava. In P. O. Hviezdoslav. Filozofická fakulta UPJŠ

Šrobárova 2

04001 Košice

Slovenská republika

E-mail: jan.gbur@upjs.sk 